\title{
Cosmos, reality and God in the letters of John
}

\author{
Author: \\ Jan van der Watt ${ }^{1,2}$

\section{Affiliations:} \\ ${ }^{1}$ Faculty of Philosophy, \\ Theology and Religion, \\ Radboud University \\ Nijmegen, the Netherlands \\ ${ }^{2}$ Faculty of Theology, North- \\ West University, South Africa \\ Correspondence to: \\ Jan van der Watt \\ Email: \\ janvanderwatt@kpnmail.nl
}

Postal address:

Paterserf 7, 6584GA

Molenhoek, the Netherlands

Dates:

Received: 24 Jan. 2013

Accepted: 22 May 2013

Published: 02 Oct. 2013

How to cite this article:

Van der Watt, J., 2013,

'Cosmos, reality and God in

the letters of John', In die

Skriflig/In Luce Verbi 47(2),

Art. \#688, 9 pages. http://

dx.doi.org/10.4102/ids.

v47i2.688

\section{Note:}

This word is broader than and should be distinguished from the concept

'cosmogony', which refers to theories about the origin of the universe, although in many cases in the New Testament material these two concepts overlap.

\section{Copyright:}

(C) 2013. The Authors.

Licensee: AOSIS

OpenJournals. This work

is licensed under the

Creative Commons

Attribution License.

Read online:
The major question addressed in this article is how reality, especially cosmic reality, is perceived in 1 John; in other words: What are the elements of John's cosmological vision as it

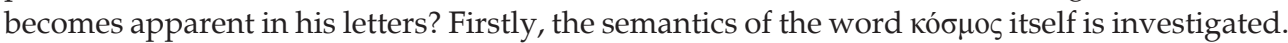
Then concepts related to the cosmological vision of John receive attention, followed by an analysis of the presence of apocalyptic elements that form part of the Johannine view of reality.

Kosmos, realiteit en God in die briewe van Johannes. 'n Sentrale vraag wat in die artikel hanteer word, is hoe die realiteit, veral die kosmiese realiteit, in 1 Johannes gesien word; met ander woorde: Wat is die elemente van die Johannese kosmologiese visie wat uit die Johannese briewe na vore tree? Die semantiek van die woord kó $\mu$ н $\varsigma$ word eerstens ondersoek, waarna konsepte wat aan die kosmiese visie van Johannes verwant is, aandag kry. Dit word gevolg deur' $n$ analise van die teenwoordigheid van apokaliptiese elemente wat deel uitmaak van die Johannese siening van realiteit.

\section{Introduction}

How is reality, especially cosmic reality, perceived in 1 John? In other words, what are the elements of John's cosmological vision as it becomes apparent in his letters? Crucial to such a question is what should be understood under the term cosmology, ${ }^{1}$ since that will determine the scope of the analysis. Views and definitions differ in this regard, and dealing with ancient 'cosmology' further complicates the picture due to the difference in worldviews between then and now. As used in this article, the concept of cosmology refers to the origin, nature, evolvement and final fate of the universe. Oden (1992:1162) opines, 'A cosmology (kosmos + logia = 'report') is a blueprint or map, in the widest sense, of the universe as a comprehensible and meaningful place.' Based on this, the way in which the concept of cosmology is treated in this presentation refers to the total dynamic mental picture (which includes any references to origin, functioning, order, nature, structural interaction and final destination) of the universe (not only the created world), including both the physical and transcendental realities as they are described in these letters. The latter remark is especially important, since the aim is not presenting a comprehensive 'cosmology', but to describe the 'cosmological views' as they are specifically found in the letters of John. Obviously, the letters of John were not written with the purpose of developing, presenting or discussing a particular cosmology. It was, however, written with a specific cosmic vision of how things in this reality are organised, function, et cetera - suggesting a particular cosmological frame within which events take place and persons exist.

Where does one start in surveying such a broad theme? The term кó $\mu$ os is used 23 times in the letters of John and serves as an ideal starting point. Semantically, it must be remembered that the content of a concept like the cosmological vision of John in his letters cannot be restricted to the analysis of one word - the conceptual use in a wider sense should also be considered. Therefore, in this article the semantics of the word кó $\mu$ o $\varsigma$ itself will first be investigated, then concepts related to the cosmological vision of John will receive attention, followed by an analysis of the presence of apocalyptic elements in the Johannine view of reality.

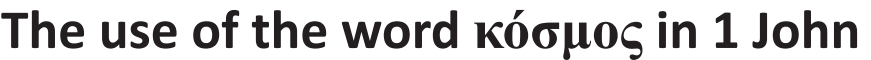

The word кó $\sigma \mu \varsigma^{1}$ is not used in one single meaning in the Gospel of John, nor in his letters. ${ }^{2}$ This is of course in line with the lexicographical potential of the word that in any case covers a wide range of possible uses. ${ }^{3}$

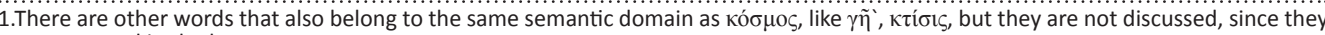
are not used in the letters.

2.It is used 22 times in 1 John $(2: 2,15[3 x], 16[2 x], 17 ; 3: 1,13,17 ; 4: 1,3,4,5[3 x], 9,14,17 ; 5: 4[2 x], 19)$ and once in 2 John 7 .

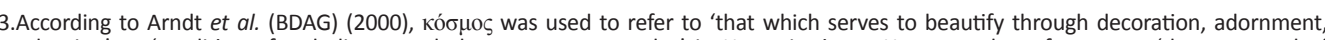
adorning' or 'condition of orderliness, orderly arrangement, order' in Homeric times. However, the reference to 'the sum total of everything here and now, the world, the (orderly) universe' is attested much wider, even in the New Testament. In a more specific sense, it is also used to refer to 'the sum total of all beings above the level of the animals, the world', or more specific, 'humanity in general'. In a broader sense, it is used to refer to 'planet earth as a place of inhabitation, the world', indicating the habitation of humans and standing 
The cosmology of John is not restricted to the use of the

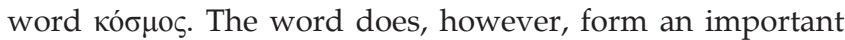
departure point in considering the cosmology as reflected in the letters, since it shows something of the understanding

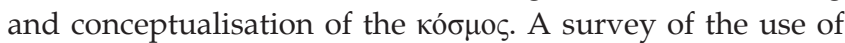
this term in 1 John allows for the division into four major categories, ${ }^{4}$ namely (cf. Brown 1986:223-224 for analysis):

- the physical or earthly reality people live in

- all human beings

- human beings not believing in God

- the ungodly reality that stands in opposition to God. ${ }^{5}$

\section{The physical or earthly world people live in}

In an explanation of what love involves, the author of 1 John (from here John) gives an example of what it means for a believer to lay down his life, by saying in 1 John 3:17:

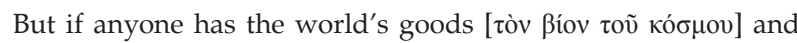
sees his brother in need, yet closes his heart against him, how does God's love abide in him?

This fictive description addresses a person who has tòv Bíov

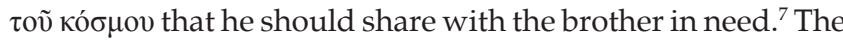
reference is to things that are found in this physical world, or reality as habitat for humans, and what we need to survive, as is implied by the reference later on in the verse to a brother who is in need. Here we have a 'neutral' reference to creation, and although there is no reference to creation in the letters, it may be assumed that the creation theology of John 1:1-18 lies behind the thinking in the letters, as Painter (2000:ad loc) also remarks: 'Whilst there is no explicit teaching on creation, the teaching of the Gospel, which seems to underpin that of the Epistles, should be presupposed.'

\section{All human beings}

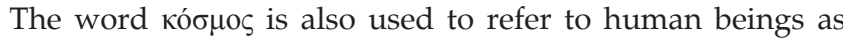
such. For instance, many false prophets (1 Jn 4:1) or deceivers

(Footnote 3 continues ...)

in contrast to heaven. BDAG (ibid) further distinguish 'the system of human existence in its many aspects, the world', including joys, possessions, sufferings, et cetera as a possible reference. In a very broad sense, it may refer to the 'collective aspect of an possible reference. In a very
entity, totality, sum total'.

4.The underlying theory used in analysing the meaning of the concept of cosmology is based on two pillars. The lexicographical potential of a word, as it is reflected in major dictionaries like BDAG (2000) and Louw and Nida (1996). This potential of the word is then considered with its associative use in the text (cotext), which associatively activates a particular usage. However, the presence of a concept in a document is not restricted to the use of a single term or terms, but also to the presence of comparable ideas or concepts. The analysis of the cosmology in the Johannine Letters will therefore not be restricted to the use of the word kó $\sigma \mu \mathrm{s}$.

5.It must be noted that 1 John is the major source of information, although 2 and 3 John also makes some contribution. If there is reference to $1 \mathrm{John}$, only the chapter and verse(s) will be referred to (i.e. 3:14) whilst 2 or 3 John will be added if the reference is to them (i.e. $2 \mathrm{John}$ ). When the reference is to another book, the name of the book will be placed before the chapter and verse.

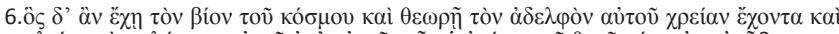

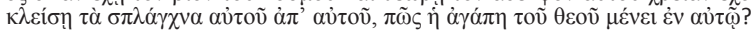

7.Surveying some translations, the word is translated as:

- 'world's goods'(NKJV; ESV; NASB; NRSV); 'goed der wereld' (Statenvertaling); 'Welt Güter' (LU 84); 'goed van die wêreld' (1983 Afrikaans translation); 'world's means' (NAB).

- 'earthly possessions' (ISV); 'irdischen Besitz' (REB); 'material possessions' (NIV).

- 'in de wereld een bestaan heeft' (1951 Dutch translation); 'qui est riche' (BFC).

8.Cf. Westcott (1892:114), Haas et al. (1972:54-55) and Bultmann (1973:116) who talk about the 'passing world'. Schnackenburg $(1984: 1990)$ uses phrases like 'irdischen Gutes', Brown (1986:449) - 'this world's livelihood' and Strecker (1989:189) Gutes', Brown (1986:449) - 'this world's livelihood' and Strecker (1989:189) -
'vergänglichen Welt'. Klauck (1991:212) puts it this way: 'Das Leben in der Welt 'vergänglichen Welt'. Klauck
erfordert Mittel zum Leben'.

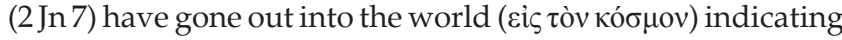
that the spirit of the antichrist is in the world already ( $\dot{\varepsilon} v \tau \tilde{\omega}$ кó $\mu \omega$ in 4:3), in other words, amongst people in general. Although it might be argued that these references to the false prophets and antichrists are either to the world as place (Bultmann 1973:63; Haas, De Jonge \& Swellengrebel 1972:116 talks about the 'sphere' where the antichrist is working) or people who do not belong to God (Smalley 1984:225, 227), the most probable reference is to people in general (implied by Marshall 1978:208), since the prophets and deceivers work amongst people. It could also, and perhaps especially, be amongst the believers whom they want to deceive, which focuses these references on all people. Like Jesus, others are also at work amongst all the people of the world, in this case believers and unbelievers. As Smalley (1984:259) says, the world is 'not only the place where God is at work for man's salvation, but also the sphere where evil forces may be active' ${ }^{9}$

\section{Human beings not believing in God, id est without relation to God}

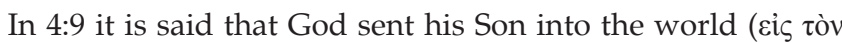

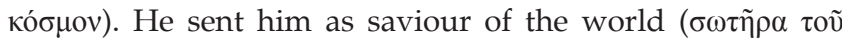

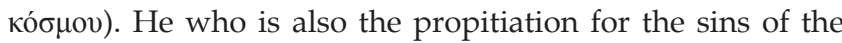

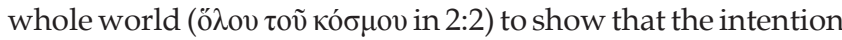
of God is not to save only some, but everybody who cares to believe in Jesus (5:11-13; cf. Smalley 1984:40; Brown 1986:224; Strecker 1989:94; Painter 2002:159). These references seem to have all people in mind (Haas et al. 1972:55), but typify them as people who need salvation, thus as people not belonging to God (yet). ${ }^{10}$ The initial mission of Jesus was to a total world in darkness in need of salvation. This corresponds to the 'negative' anthropology of the Johannine material, typifying all people as being in darkness and in need of salvation. It should, however, be noted that this use is contextually determined. Jesus was initially sent to an unbelieving world, but when some believed, it did not mean that Jesus was not sent for them any longer. In these contexts, this latter aspect

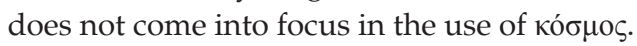

In 3:1 and 13 it is stated that the world does not know God and his people and that it hates believers. The reference of 'world' here is to people who do not know God or Jesus (3:1) and stand in active opposition to believers by hating them. ${ }^{11}$ The same reference seems to apply to the usages of

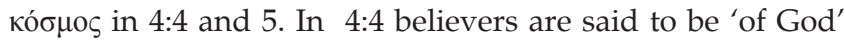
( $\dot{\varepsilon} \kappa \tau$ ๆ $0 \tilde{\theta} \theta 0 \tilde{v})$ and are therefore victors, since he who is in them ( $\dot{o} \dot{\varepsilon} v \dot{v} \mu \mathrm{i} v)$ is greater than he who is in the world ( $\dot{o} \dot{\varepsilon} v$

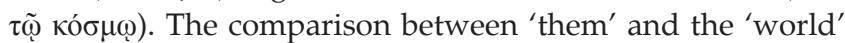
seems to focus on people in whom spirits of error and/or the antichrist(s) can work (see the immediate cotext in chapter 4),

9 .See also the discussion under the section 'Human beings not believing in God', where it is argued that the reference in 17 might also be to people in general.

10.See Brown (1986:517) who notes that Weiss wants to see the use as negative,

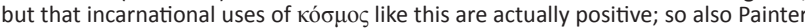
(2002:159), Menken (2010:88) and Marshall (1978:214) by implication. Smalley 1984:227 wants to see the use as 'neutral', thus missing the emphasis on people in need of salvation.

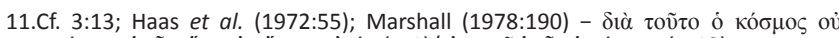

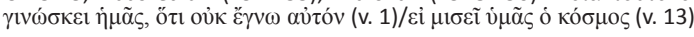


implying that the 'world' here should be understood in terms of unbelievers (Haas et al. 1972:55; Smalley 1984:225; Painter 2002:262; Menken 2010:82). In 4:5, the word кó $\sigma \mu \circ$

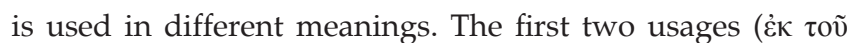

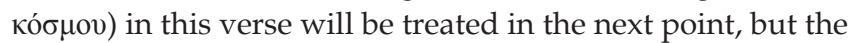
last reference to the 'world' who will listen to those (ó kó $\sigma \mu$ os

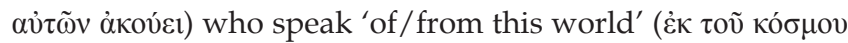
$\lambda \alpha \lambda$ oṽ $\sigma \mathrm{v})$ is evidently also to the people who do not believe.

The reference in 4:17 is ambiguous, namely, 'as he is so also are

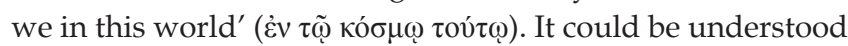
as referring to the world as dwelling place, people or to people who do not believe. Painter (2002:281), for instance in his commentary on $4: 17$, moves between the meanings of 'unbelieving people' who did not recognise Jesus (using Jn 17:9-26 as parallel), and the world as place where Jesus is no longer since he went to the Father. Strecker (1989:251-252) seems to interpret the world in this verse as referring both to people who do not believe and people in general when he says: 'So muss es geschehen, wo die christliche Gemeinde ihren Auftrag wahrnimmt und ihr Agapesein in der Welt als verbindlichen Auftrag für die Welt versteht' (Strecker ibid:252). Love must be expressed 'in und an der Welt' (Strecker ibid:251), which includes love for one another as well as for unbelievers (i.e. it includes everybody, both believers and unbelievers), as the context of 4:17 indicates. Menken (2010:94) does not address the problem directly, but seems to insinuate that as Jesus was amongst the people of this world, believers are also amongst the people of this world, i.e. people in general (this could imply that classification under the section 'All human beings' above is also a possibility). Smalley (1984:259) refers to John 17 as interpretative framework and argues that the 'church', or believer, is distinguished from the world, which implies that the 'world' here refers to people who do not believe.

\section{The ungodly reality standing in opposition to God}

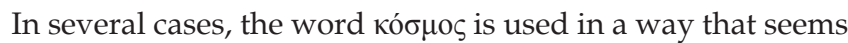
to refer to a more general, inclusive reality - including more than just humans (against Kruse 2000:149). It seems to refer to an ungodly reality, including spiritual powers (though not necessarily) that may be distinguished from and stand opposed to God (Brown 1986:498 refers to the 'realm of hostility to God'). In 4:5 it is mentioned that there are people

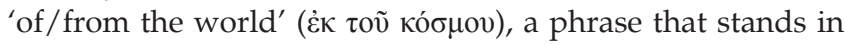
direct opposition and in contrast to ('im schärfsten Gegensatz' -

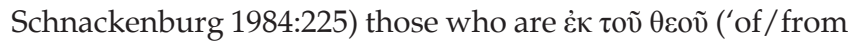
God') in 4:4. ${ }^{12}$ They are of or from this world, meaning their origin is from the world - in this context, 'world' might refer to evil as individual entity encapsulating everything that is evil. This is where these people come from. The 'cosmos' in this context is this ungodly, evil reality from where these people come and whose 'language' they speak (Smalley 1984:227; Strecker 1989:216). It typifies them as not being of God - to the contrary.

12.Painter (2002:263) recognises the references to God and the world in $4: 4$ and 5 as an 'antithetic parallelism'.

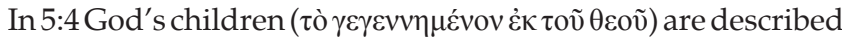

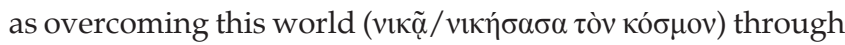
faith. Those people who are 'of God' stand as victors over the world. This seems to describe an existential contrast. The reference here could obviously also be to unbelieving people (see the section above titled 'Human beings not believing in God, i.e. without relation to God'), but in this context it seems more plausible to understand the use as referring to the world as entity opposed to God, including everything also the evil spirits and the devil (3:4-10). ${ }^{13}$

The six occurrences of the word кó $\mu$ os in 2:15-17 present a small dynamic image of the opposition between God and

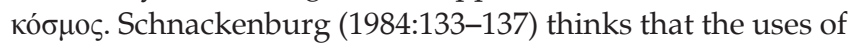

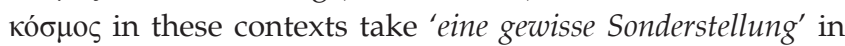
the Johannine literature. The кó $\sigma \mu \mathrm{s}$ is pictured as an entity with the following characteristics:

1. It could be loved and apparently therefore serves as temptation (Marshall 1978:142).

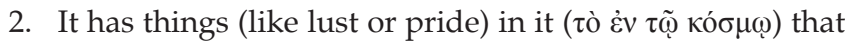

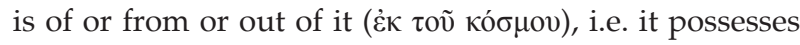
things and things have their origin in it. These references

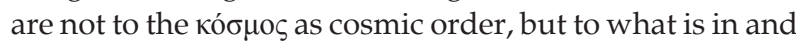
of this кó $\mu_{0}$ (Smalley 1984:87), which obviously carry its characteristics.

3. It will pass away with everything in it that came out of it.

In each case there is a contrasting remark, namely that love of the 'world' means a person does not have the love of God in him, or that the things that have their origin of the world, and are therefore in the world, are not of God, or that in contrast to the 'world' that will pass away, the person who does the will of God abides forever. In this sense one can say that the 'world' here represents a reality (including negative attitudes - Haas et al. 1972:55; Smalley 1984:86) that opposes the divine reality (Klauck 1991:138) - both on the level of existence (lust comes out of the world) as on ethical level (lust does not correspond with the love or will of God). ${ }^{14}$ It does not only refer to people or to physical things (i.e. hating the material world - see Marshall 1978:143; Schnackenburg 1984:134), but to a separate reality that opposes God, which of course includes lusting people, but also lust as such. It might also include lifestyles that were linked to practices of lust, like feasts. Dodd (1946:42) also thinks it refers to the contemporary pagan society with everything associated to it. The contrast here represents a cosmological division between God and the evil world (cf. Smalley 1984:81). They stand opposed to one another and do not overlap. Both the physical and the spiritual realities are included in the use here.

In 5:19 we read: 'We know that we are of/from God, and the whole world lies in the power of the evil one.' This expression (especially 'whole' world) provides some problems as to how

13.Cf. Smalley (1984:270); Westcott (1892:144). Schnackenburg (1984:253) emphasises the scope of кó $\mu_{\mu \circ}$ here by describing its reference as 'alles Gottfeindliche'. Marshall (1978:209) restricts the reference of кó $\sigma \mu \mathrm{s}$ to those in opposition to God, as well as their evil attitudes; see also Kruse (2000:172).

14.Smalley (1984:86) argues that this is not a cosmological contrast, but an ethical one. The main emphasis in these verses is indeed proper behaviour, but the distinction between God, his love and permanency, and the world do carry implicit spatial differentiation. God's reality should be distinguished from this reality. 
to understand it. Brown (1986:623) rejects the possibility of translating it as 'the world as a whole', something Westcott suggested. On the other hand, it cannot carry the same meaning as in 2:2 (cf. the previous subsection titled 'Human beings not believing in God'; Klauck 1991:338; Smalley 1984:304) - referring to all the people of the world - since believers are clearly excluded here. The opposition to God and his people is clear. The evil one is distinguished from the 'world' since he is holding the world in his power - there is the idea of dependence on the evil one (Brown 1986:623). It therefore seems as if the 'world' as entity, both people and what else could be associated with the world, namely lust, pride, et cetera is intended here. The reference seems to be bit broader than simply unbelieving people.

\section{Main features}

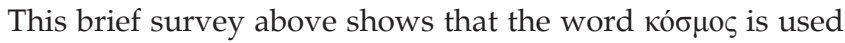
in different ways in the letters, depending on the cotext.

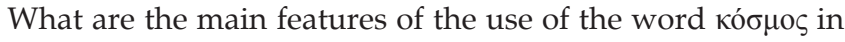
the letters?

- The word is used to refer to (1) the world as physical reality forming the habitat people need to exist, (2) people, both in general and people without a relationship with God, and (3) the evil reality that stands in opposition to God.

- As habitat it refers to the created order where people live, without any moral or other underlying implications. No indication is given of how and where the world comes from, but in the light of the creation theology of John 1:1-18 it can be assumed that God is the creator. The devil, who sinned from the beginning (3:8), is also just announced, without any indication of the origin of the devil and also without any discussion why the

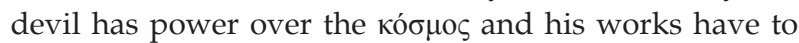
be destroyed. Looking at these statements, it must be assumed that there were theological explanations behind these statements that are not developed or discussed in the letters. In other words, the letters are embedded in an assumed broader theological framework. In Johannine studies it is assumed that the Gospel tradition forms this interpretative framework, but it will be argued later on that apocalyptical ideas are part of this cosmological framework, suggesting that 1 John also reflects other early Jewish-Christian traditions:

- The reference to people in general, picture them as people who are by implication also moral agents amongst whom the false prophets work. They are portrayed as people who should and can make a choice. These are the people to whom God sends his Son who should be believed in (Jn 3:16).

- The references to unbelievers, as well as to the evil reality (see subsections 'Human beings not believing in God' and 'The ungodly reality standing in opposition to God' above) are basically theological in nature and present these evil realities according to their relationship to God. The cosmology is here formulated and developed in terms of relationships with God, i.e. in theological categories.

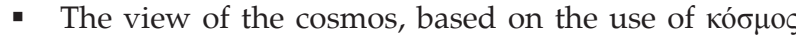
in the letters, is that there is a physical reality with people living on it. This physical reality is impacted by spiritual realities and this becomes evident through the attitude and actions of people. Both the physical reality and the evil spiritual reality with everything it includes (even the devil or evil one) are in some cases covered by the word кó $\mu$ os. However, there is no indication that God or the Spirit is included in the reference field of кó $\sigma \mu$ os.

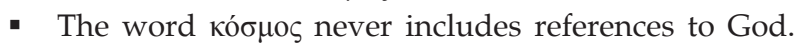

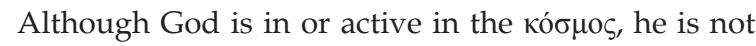
designated as part of the field of reference or semantic

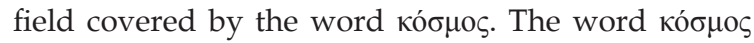
does not refer to the all-inclusive universe, but distinguishes God from the earthly world with the people in it (including their goods and lusts), just as the creation and creator is distinguished, or ethically as good and evil is distinguished.

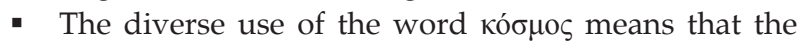
usages might refer to different existential situations of people. People who are begotten of God are described as not being part of the кó $\mu$ o $\varsigma$ and indeed stand in opposition to the кó $\mu$ o $\varsigma$ (5:4), although another sense they were part of it before their spiritual birth and as physical people still remain dependent on the goods of this world (3:17). In this sense, they are still part

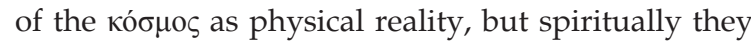
cannot be designated as being part of the кó $\sigma \mu \mathrm{o}$ in the sense of unbelievers or of the evil reality. This way of using a word requires a certain semantic sensitivity. The word does not have a fixed meaning, and the reader is dependent on the context for determining its meaning. However, one should not conclude that the word brings nothing of its own to the text - the fact that John does not use the word to refer to God, shows that he does respect the lexicographical potential of the word in the sense that God cannot be part of the

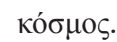

- John presents his cosmological ideas in strong theological terms - it is considered in terms of the relations of the different aspects to God. It is not a creational cosmology, but a theological cosmology. Within this cosmology, relational and ethical cosmological reflections are dominant.

\section{Some reflections on the transcendental realities forming part of the universe}

Surveying a concept cannot simply be restricted to the use of a word or words belonging to the semantic domain of that particular concept. It may also be developed in other descriptive ways. ${ }^{15}$ We will now turn our attention to a few remarks on the further conceptual development in 1 John.

15.For example, one needs not to use the word winter to describe that time of year descriptions like 'the snow is falling and it is very cold, it is that time of year again' would refer to winter without the specific use of the word. 


\section{Spatially distinct: Indirect spatial references - a

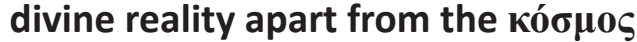

Spatial contrasts like heaven and earth, above and below, which are typical of the Gospel, are not directly mentioned in the Johannine letters. As was seen above, the alternative reality of God (i.e. the above, the heaven, to use Gospel terms) is distinct from and stands in contrast to кó $\sigma \mu \rho \zeta$. It is inter alia indirectly referred to in what could be called spatial terminology, but that is not all. Qualitative descriptions dominate, giving the cosmology its distinct theological and ethical character.

Verbs of action or movement confirm a reality outside this

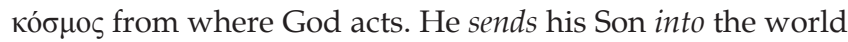

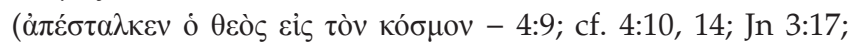

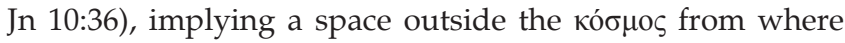

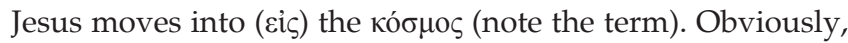
if the receivers of this letter were in any way acquainted with the contents of the Gospel - which they most certainly were ${ }^{16}$ - the idea of heaven or the above from where Jesus came that stood over and against the earth or below (Jn 3:31; 8:23), would most certainly have been recalled.

The return of Jesus to his Father in heaven, which plays such an important role in the Gospel (eg. 3:13; 6:62; 20:17), is also not explicitly mentioned, but obviously assumed as part of the implicit knowledge of the recipients of the letters. This would form the natural spatial framework for remarks that

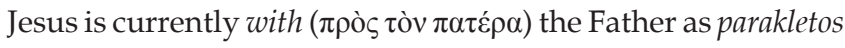
( $\pi \alpha \rho \alpha \dot{\kappa} \lambda \eta \tau \circ \varsigma-2: 1)$, but also of his expected appearance at his return from where he now is $(2: 28 ; 3: 2)$. This implies spatial distance between what is covered by the word кó $\sigma \mu \mathrm{os}_{\text {, and the }}$ Father and Son. It is evident that the spatial framework of the letters assumes that of the Gospel, but it is not foregrounded.

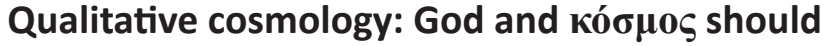 qualitatively be distinguished}

God presents a transcendental reality that is qualitatively ideal and perfect in contrast to evil. This is expressed in different qualitative ways. God and Jesus is sinless $(3: 5,8)$, the truth (4:1-6; Smalley 1984:215), and righteous (2:28); the light that shines in darkness (1:5; 2:8-11; Brown 1986:225$230)$, and love that overcomes hatred (4:8, 16; Schnackenburg 1984:228). God is also qualitatively superior. He is greater

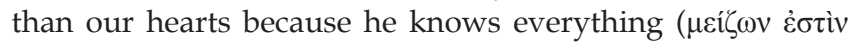
ó $\theta \varepsilon \dot{\varsigma} \varsigma \tau \tilde{\eta} \varsigma \kappa \alpha \rho \delta i ́ \alpha \varsigma \dot{\eta} \mu \tilde{\omega} \nu-3: 20)$ and his testimony is greater than that of men, since he cannot lie (5:9-10). $\mathrm{He}^{17}$ is also greater than he (i.e. the devil or evil one) who is in the world

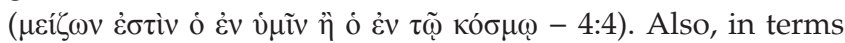
of qualitative existence God is superior. In contrast to the

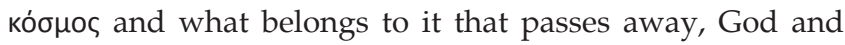
the one associated with God abides forever (2:17; Painter

16.For the relation between the Gospel and the letters, cf. Marshall (1978:31-42) Schnackenburg (1984:34-38); Brown (1986:14-35); Painter (2002:58-74); Van der Watt (2007:22-25); Menken (2010:10-12).

17.The 'he' that is greater than the one in the world (4:4) is most probably referring to God (Haas et al. 1972:117), but it could also refer to God in Jesus or even the Spirit. Smalley (1984:227) argues that no choice should be made, since all these meanings are intended.
2002:195). This is a direct allusion to that which is permanent vs. what is earthly and decays (also implying the end of this created world - Smalley 1984:87; 1 Cor 7:31; 2 Pt 3:7-13; Rv 21:1-4), expressing a common ancient strive for permanency (Is 40:6-8; Job 14:1-4; Ps 90; Ja 1:9-10), which the earth and what belongs to it cannot offer.

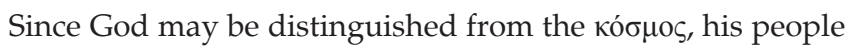
are also to be distinguished, as the contrast between God's people and the world (5:19) or evil (3 Jn 11) illustrates. By receiving eternal life, they can be qualitatively distinguished

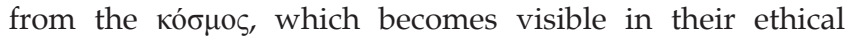
behaviour. In this sense, the qualitative en ethical overlap. Although people are all present on this earth, they are spiritually to be distinguished. Evil will not be able to touch God's people (5:19) and they will not imitate evil (3 Jn 11) - another illustration that the cosmology is expressed in theological categories.

In short, the use of the word кó $\mu$ os does not cover the spiritual reality related to God, which forms a different dimension of cosmology. It is clearly distinct from the кó $\mu$ o $\varsigma$ and this is expressed within a cosmology that is constructed via qualitative and ethical distinctions.

\section{Bridging the cosmological gap}

Nobody has seen God $(4: 12,20)$ and the categories covered

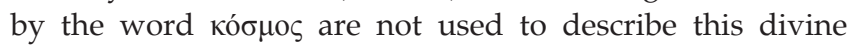
reality (Bultmann 1973:156-157; Kruse 2000:161-162). The presence of Jesus is the major way in which this invisibility of the divine in this world is broken - he came in flesh, a major point of contention within the Johannine framework. This implies his pre-existence. The presence of the divine, eternal life, truth and righteousness $(2: 1,29)$, becomes visible through the presence of the fleshly Jesus, the bringer of life (1:1-3; Bultmann 1973:10-20), who became flesh (4:2) and who could be observed, heard and touched (1:1-3). In the incarnation of Jesus, the divine reality 'physically entered' into this historical world. As a human he was life, but he also brought eternal life. He offered believers the example of what the divine reality looks like in human form - an example that should be followed (2:6). He then becomes the route or bridge people may use to become part of the divine reality. By believing in him, people are begotten of God and become children of God.

An important anthropological point that has bearing on the cosmology and which is typical of Johannine theology, should be noted here: becoming part of the family of God means passing from death into life (3:14; Painter 2002:239241). The view of people are that they are all dead and are therefore part of the reality of the evil one and are indeed in his power - except if they become part of the family of God (5:19) through Jesus. Anthropologically, people are seen to be children of the devil, and they cannot change their ontological status. This negative anthropology functions as a point of departure. In Jesus, however, the divine life becomes physically available and accessible. This changed the 
ontological and cosmological possibilities of people. Humans are now enabled to partake in the transcendental reality by receiving eternal life through their union with Jesus. In other words, by believing in him, they receive the ability to enter into an intimate relationship with the transcendental God they are born into the family of God (see the filial language such as being born, father, son, etc. in the letters; see also Van der Watt 1999; Van der Merwe 2006). They are indeed 'begotten of God ... for God's nature abides in him' (3:9). On the one hand, they are part of an earthly family as part of this human world, but by receiving life they are also born into the transcendental family of God. To put it differently, in Jesus a new 'species' came into being, namely a 'species' that is a human on this earth, but who also shares in the divine reality of God. They are part of the divine reality, but physically still remains in this physical world with its existential and ethical challenges. Two realities merge in one person: the transcendental and the earthly. The believer is changed in his being and that must be expressed in the physical world through their moral behaviour, but the believer is still fully flesh in this world, which challenges them ethically. In him two realities are united, which opens the way for other people who believe in him to become 'of the same species'. In Christ the essential nature of cosmology changed.

Obviously, this could create problems of its own, especially in a group-orientated society where the identity and lives of individuals were dependent upon and determined by the group ethos of their family in formulating their own identity. Belonging to two families will result in split loyalties and eventually conflict. Which group's ethos should be favoured and followed? Which family is primary in forming a person's identity and consequent behaviour? According to John, it is the family that belongs to God. He is light, and believers should act as people who belong to the light (1:5-8). Any action orientated towards a person's own desires is regarded as loving this world and not as love of God (2:15-17).

One aspect must be emphasised a bit more. As was argued, the transcendental reality is not directly visible in or to the earthly or physical reality, except for Jesus who came in the flesh. Nobody has seen God, or the devil for that matter (4:12, 20). Nevertheless, within people the spiritual reality and the earthly reality overlaps, i.e. both could and are present within the same space (person). Within such a person, there is interaction between these two realities. A human can either remain in God or be part of the family of the devil (3:9-10). The presence of this spiritual reality (either divine or evil) in humans becomes visible in different external ways, namely by remaining in the confession (4:15) and word or commandments of Jesus $(2: 5,14,24 ; 3: 24 ; 2$ Jn 9), which imply concrete actions according to these commandments, and these actions involve remaining in love $(2: 15 ; 3: 17 ; 4: 9,12)$ and righteousness (2:28-29).

These actions are inter alia inspired by the Spirit that represents a way in which the divine reality is present and interacts with people as 3:24 says:
All who keep his commandments abide in him, and he in them. And by this we know that he abides in us, by the Spirit which he has given us.

The spirit(s) form the interface between the spiritual realities and the physical human reality: people experience God through the Spirit (Schnackenburg 1984:208-209; Klauck 1991:225-226) and stand under the guidance of spirit(s) (Brown 1986:465-466). Which spirit is working in a particular person becomes evident in activities, like confession, prophecy and moral actions. In 4:1-6 the presence of the Spirit of God is evident in the confession of Jesus as the truth. The Spirit (the word 'anointment' is used here) also teaches them in truth - an action that was necessary if you are part of a new family (2:20-27). It seems plausible to argue that what happens within the group that is in line with the truth could be attributed to the Spirit.

Cosmology and anthropology thus overlap. The earth, and specifically people, is the sphere where different cosmological realities overlap and interact. In this sense, humans are the 'space of unfolding cosmology', although the cosmology is theologically determined.

Brief attention should also be given to the description of the devil within the cosmological framework. Within the spiritual reality there is also opposition, namely between the reality characterised and defined by God and the reality characterised by the devil. Both these spiritual realities overlap with the earthly, or physical, world, but they do not overlap one another; they stand in absolute opposition.

The devil was there and sinned from the beginning (3:8) as transcendental opposing power to God. No indication is given where the devil comes from and why the devil opposes God. These things are simply assumed (cf. Bultmann 1973: 99-100, Keener 1993:ad loc. for possible roots). It is stated that the power of the devil was of such extent that the Son of God had to appear to destroy his works. However, it is not completely destroyed, since the devil, or the evil one, still has

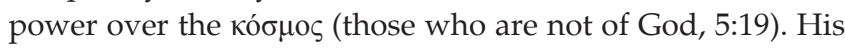
powerful expressions comes in the following forms:

1. The antichrist (2:18), whose works are evident in the actions of those who are no longer in the midst of the believers (cf. Schnackenburg 1984:145-149; Brown 1986:333-337; Klauck 1991:149-150).

2. The spirit of error, or of the antichrist, whose presence is visible through the false prophets $(4: 1-6$; Brown 1986:489-491).

3. Cain, as symbolic expression of those who murdered his brother like, yes, all those who do not care for believers (3:11-18; Painter 2002:238-240; Thatcher 2012:350-373).

In short, opposing the spiritual realities (of God and the devil) overlap with the earthly reality, and as such influence the earthly reality. The influence is evident in the actions of people that are influenced by spirit(s) representing each reality. This confirms that the way the letters view this reality is essentially theologically determined, and is presented and 
described in those terms. The events on earth is understood and explained in terms of the presence of spiritual realities that determine the morality of the people on earth, whilst there is no development of, for instance, biological, or natural, cosmological categories - the worldview and its narrative are not developed in these terms.

\section{Some apocalyptic categories ... And the cosmology of 1 John}

An important aspect of cosmology is the way in which the cosmos will end, although that might often be expressed in theoretical or mythical terms. The cosmological drama in 1 John has apocalyptic traits (cf. Bultmann 1973:35-36; Strecker 1989:62-63; Menken 2010:47-48 sees early Christian traditions as the foundation of the Johannine ideas here). Two opposing spiritual powers stand in conflict in this world, namely the divine and the evil powers, God and the devil. This physical world is therefore typified in terms of this (final) conflict. However, the presently bad situation will change to an ideal one in the future, which is the hope of believers (3:1-3). But this will only happen within the escalating presence of evil in the form of the antichrist, deception and false prophets.

Firstly, there are some references to the cosmic battle. Although the conflict itself is not described in any detail, like for instance in the Apocalypse, the use of certain concepts within the argument implies an underlying presence of such an eschatological conflict:

- The destruction of the works of the devil by Jesus is highlighted in 3:8. This does not imply a total destruction of the presence of the devil in this world, since the evil remains a serious factor in the everyday experience of the Johannine group. Not only is the 'whole world [except the children of God] in the power of the evil one' (5:19), but the Johannine group concretely experienced the destructive presence of the antichrists $(2: 18,22 ; 4: 3)$ and false prophets who act under the influence of the spirits of error (4:1-6) and in opposition to the authority of the elders (3 John), something that does not reflect behaviour in the truth. The physical world is the place where the spiritual battle between good and evil cosmically unfolds. People are influenced by the spiritual reality, which is qualitatively distinguished as being either good or evil. The spirits of error work in false prophets as the Spirit of truth works in the believers, impacting on their lives and actions. The 'battle' between good and evil, truth and error, becomes evident in the actions, desires and groups alliances of people. Believers have the anointing that teaches them and keeps them in truth (2:27). The people of the world hate believers and even kill them, because these people of the world are from the evil one (3:11-13). Believers, however, passed from death to life and live a life of truth (3:19) and love for one another (3:14-17). This final conflict is related to the 'last hour' (2:18), an apocalyptical expression (cf. Smalley 1984:101; Marshall 1978:148).
The presence of the antichrists ${ }^{18}$ is directly linked to the arrival of the 'last hour' (2:18), a term linked to the final eschatological events (Klauck 1991:234; Brown 1986:497). The phrase 'last hour' occurs only here in the New Testament, but the absence of an article ( $\dot{\varepsilon} \sigma \chi \alpha \dot{\tau} \tau \emptyset \ddot{\omega} \rho)$ might suggest that it was a general and well known phrase in Greek (Haas et al. 1972:61; Smalley 1984:95), although Bultmann (1973:36) suggests that the term might stem from Jewish apocalyptic (Smalley ibid:95-96 describes the development of the idea of a time that will precede a final consummation). It seems to refer to the period of escalating evil before the final parousia and judgment (Smalley ibid:95), meaning that the 'community's own story is being played out in the immediate context of apocalyptic events of the end time' (Strecker 1989:63).

- There is therefore indeed a power struggle that still rages, but the outcome is fixed and anticipated in hope $(3: 2)$. Believers have conquered the evil (2:13-14; 4:4; 5:4-5). They are described as being strong (2:14). This power should apparently be linked to their faith in Jesus, as it is stated in 5:4-5, namely that 'this is the victory that has overcome the world - our faith in Jesus' (Bultmann 1973:179-180 talks of 'apocalyptic rests' here). Standing in an intimate relation to him implies sharing in his power and victory. The eschatological certainty exists that the evil is overcome and the eschatological hope exists that evil will be changed into good, or impurity into purity (3:3). 'Who is it that overcomes the world except the one

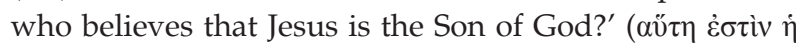

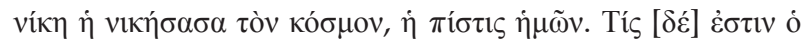

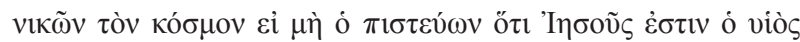

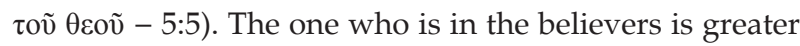
than he who is in the world (4:4), and the power of the believers comes from their relationship with God who is greater. 'For John is in no doubt about the ultimate outcome of the conflict ("he in you is more powerful"). ${ }^{19}$ With such an assurance, victory in the present encounter between right and "worldly" wrong may be achieved by the faithful Christian' (Smalley 1984:227). ${ }^{20}$ This places John firmly within early Christian traditions regarding eschatological expectations.

Secondly, in line with apocalyptic thinking, this order of tension and conflict will be resolved through the final judgment and vindication of believers who will become like Jesus. The emphasis falls on the intensification of the evil during the last days (see also Apocalypse and 2 Th 2:1-12), the final judgment and what follows:

- There are several references to the parousia or return of Jesus (2:28; 3:2; Klauck 1991:174, 181). Brown (1986:381) argues that because the term parousia is not explained in

18.Cf. $2: 18,22 ; 4: 3 ; 2$ John 7 . See also 2 Thessalonians $2: 1-12$, Revelation $12-13$ - although the term antichrist is not used in these passages there might be conceptual link, as BDAG (2000) or Bultmann (1973:36) suggest (see also Strecker 1989:214; Smalley 1984:98-100). Marshall (1978:151) warns against an apocalyptic over-interpretation of these passages in $1 \mathrm{John}$

19.Cf. further 4:6; 5:4-5; Revelation 5:5; 12:11; 17:14.

20.Smalley (1984:227) remarks that the 'allusion to the battle between spiritual truth and error, God and the evil one, grazes the edge of dualism' a dualism which 'is ethical and not cosmic [see the comment on 2:15], Jewish and not Greek'. The ethical and cosmic cannot be separated so sharply, since the ethical flows from the ontological, which is decidedly linked to the cosmology of the letter. 
the text, it points to 'a Johannine apocalyptic tradition'. This parousia will lead to the final judgment at which point believers will not shrink from him in shame $(2: 28)^{21}$ or have fear, but rather may be confident (4:17-18). Believers now live in the eschatological hope of this return (appearance - pavepó $\omega$ ) of Christ when they will be changed to be like him, although what they will be is not known yet $(3: 2-3)$. Their calling on earth is to

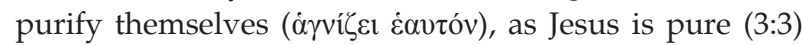
- a possible reference to what they will be. With Jesus' return, the final cosmological division will take place through the final judgment (4:17-18). The reference to the last day, together with the references to the antichrist and ensuing judgment, puts the events narrated in 1 John squarely within an apocalyptical eschatological frame.

What will happen to the evil and evil one is not developed in detail, except that it is implied that they have reason to fear related to punishment (4:18). John did not develop this any further.

- What is eventually going to happen with the return of Jesus $(2: 28 ; 3: 2)$ ? There were several models available, even within the Christian framework. For instance, Jesus taking believers to heaven (1 Th 4), heaven and earth being destroyed, but believers saved and allowed to live on the new earth under the new heaven (2 Pt 3), or alternatively that, after everybody was judged in heaven and evil punished, the new heaven will descent onto the new earth and God will dwell with his people ( $R v 21)$. There is mention of Jesus 'appearing' (3:2) or 'coming' (2:28), implying the model of Jesus returning to the abode of people and then believers will be like him (3:2). In 3:3 believers are consequently encouraged to purify themselves in the light of the hope to become like Jesus. This implies that the reality will be different, at least as far as purity is concerned.

Detail information lacks as to what exactly will happen at the return of Jesus. A few things are mentioned. There will be a judgment, which believers need not fear, but unbelievers by implication should (4:17-18; see Strecker 1989:248-249 who also interprets this verse within a Jewish apocalyptic framework). The world will pass by (2:17), most probably referring to the physical world with its lusts as it is currently known; it might be that unbelievers are included in this use

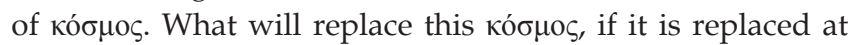
all, is not said. What is said is that Jesus will appear amongst people and then they will become like him (3:2), but where this will happen is not said. In 3:2 it is simply stated that Jesus will appear and then the change to be like him will take place, and it seems as if it will happen amongst the believers who will then be on this earth. No further remarks are found in the text. If the problem is approached from the Johannine theological perspective, it at least offers us some explanation. God's reality is not covered semantically by the word кó $\sigma \mu \mathrm{s}$, but is expressed in terms of his divine qualities. Believers (will) share in these qualities, like eternal life, truth, light, righteousness and purity. Where light shines there is 21.Klauck (1991:174) shows that this is an apocalyptic topos. no darkness - where these qualities of God are in an absolute way, there is no opposite. It might be assumed that like the

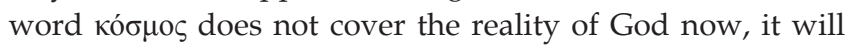
also not cover his reality and that of his people in the future. What will be is not known, but will become known when Jesus appears (3:2).

In summary, the present and future of this world is presented within an apocalyptic framework, in which the change already started, for instance, through the presence of eternal life (1:1-2; 5:10-12). Klauck (1991:291), of course, remarks that 'die Apokalyptische Komponente ist im 1Joh ganz in den Hintergrund getreten', reminding us that what we have here is not a full-fledged apocalyptic text.

The world is pictured as the battle field between good and evil, with people being under the influence of the spirit(s). This is apparent in the conflicting activities of the antichrist that marks the presence of the last day. The outcome of the conflict is already fixed by the stronger One who destroyed the works of the devil, although its power and influence have not disappeared in the cosmos. Believers, however, already experience the victory through strength that is based on their faith, although they are still experiencing the presence of evil in their earthly lives, as is clear in passages like 3:11-4, 2 John 11 or 3 John. It is not without reason that believers are warned to stay away from idols (5:21). The parousia and final judgment will see the change of the believers to be as Jesus is. What will happen to the evil and the evil one is not developed any further in the letter, except that they will have to fear.

\section{Some concluding remarks}

1. At this point we should return to the question on what exactly the term cosmology refers to. It was said in the beginning that it refers to information relating to the origin, nature, evolvement and final fate of the universe. Universe should be understood as that what could be known, even mythologically, and conceptualised in language. This definition is indeed wider than the

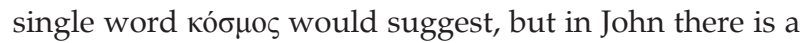
good reason for this, since the divine reality is excluded

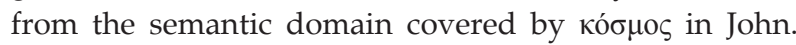
Nevertheless, the divine reality should be included in cosmology.

2. The Johannine letters do not conform to a three-level cosmology, which is often assumed to be common in the Bible, for instance in the Apocalypse. This reminds us that we should refine the way we deal with the concept of the view of reality in the New Testament. There is not necessarily only one cosmology functioning in ancient texts, but several. In the Johannine letters, the theological perspective dominates and from there a quite incomplete, but, nevertheless, very clear cosmology is presented; clear not in the sense of complete, but adequate to form a clear idea of what was intended.

3. There is no single cosmology that is the true and correct cosmology. Taking the letters as example, 
it is clear that the cosmology in John's letters is the result of, in other words follow on, the theology. In such a case, the argumentative authority lies with the theological assumptions. Theological categories and not natural distinctions dominate. In other cases, scientific observation, mythology, et cetera might form the orientating point from where the cosmology is developed. In John the point of orientation is theology. Views of the origin and functioning of the reality unfold from the perspective of who God is, what he offers and what his relation to the earth, its inhabitants and even the evil spirits is. It is therefore possible that, on the basis of this information, cosmologies may vary and do indeed vary. It further implies that several cosmologies might function at the same time in the same person. For instance, the theologically dominated cosmology of the letters might co-exist with a natural scientific view within the same person, each functioning within its own context with its same presuppositions. As such, 'cosmologies' are constructs of reality that serve as 'vehicles' within which specific issues and questions related to cosmic reality are addressed and reality explained.

4. 1 John does not offer a full cosmology, but a functional theological cosmology that branches out into spiritual and ethical categories. It is within such a framework that we should appreciate and evaluate the view of reality found in the Johannine letters.

\section{Acknowledgements \\ Competing interests}

The author declares that he has no financial or personal relationship(s) that may have inappropriately influenced him in writing this article.

\section{References}

Arndt, W., Danker, F.W., Bauer, W. \& Gingrich, F.W., 2000, A Greek-English lexicon of the New Testament and other early Christian literature, University of Chicago Press, Chicago.

Brown, R.E., 1986, The Epistles of John, Doubleday, New York.

Bultmann, R., 1973, The Johannine Epistles, Fortress, Philadelphia. PMCid:PMC422915

Dodd, C.H., 1946, The Johannine epistles, Hodder \& Stoughton, London.

Haas, C., De Jonge, M. \& Swellengrebel, J.L., 1972, A Translator's handbook on the letters of John, United Bible Societies, New York.

Keener, C.S., 1993, The IVP Bible background commentary: New Testament, InterVarsity Press, Downers Grove.

Klauck, H-J., 1991, Der Erste Johannesbrief, Neukirchner Verlag, Neukirchner. PMid:2011596, PMCid:PMC51340

Kruse, C.G., 2000, The letters of John, Eerdmans, Grand Rapids.

Louw, J.P. \& Nida, E.A., 1996, Greek-English lexicon of the New Testament: Based on semantic domains, United Bible Societies, New York.

Marshall, I.H., 1978, The Epistles of John, Eerdmans, Grand Rapids.

Menken, M.J.J., 2010, 1,2 en 3 Johannes, Kok, Kampen.

Oden, R.A. Jr., 1992, 'Cosmogony, Cosmology', in D.N. Freedman (ed.), The Anchor Yale Bible Dictionary, vol. 1, pp. 1162ff., Doubleday, New York.

Painter, J., 2000, 'Creation, Cosmology', in R.P. Martin \& P.H. Davids (eds.), Dictionary of the later New Testament and its developments, pp. ad loc, InterVarsity Press, Downers Grove.

Painter, J., 2002, 1, 2 and 3 John, Liturgical Press, Collegeville.

Schnackenburg, R., 1984, Die Johannesbriefe, Herder, Freiburg/Basel/Wien.

Smalley, S.S., 1984, 1, 2, 3 John, Word Biblical Commentary, Waco. PMCid:PMC271543

Strecker G., 1989, Die Johannesbriefe, Vandenhoeck \& Ruprecht, Göttingen. PMCid:PMC1280535

Thatcher, T., 2012, 'Cain the Jew the AntiChrist: Collective memory and the Johannine ethic of loving and hating', in J.G. van der Watt \& R. Zimmermann (eds.), Rethinking the ethics of John, pp. 350-373, Mohr Siebeck, Tübingen.

Van der Merwe, D.G., 2006, 'A matter of having fellowship: Ethics in the Johannine Epistles', in J.G. van der Watt (ed.), Identity, ethics, and ethos in the New Testament, pp. 535-563, De Gruyter, Berlin. http://dx.doi.org/10.1515/9783110893939.535

Van der Watt, J.G., 1999, 'Ethics in First John: A literary and social scientific perspective', Catholic Biblical Quarterly 61, 491-511.

Van der Watt, J.G., 2007, An introduction to the Johannine Gospel and Letters, T\&T Clarke, London.

Westcott, B.F., 1892, The Epistles of St John, Logos Bible Software. 